\title{
Iceland should replace its central bank with a currency board
}

FREDRIK NG ANDERSSON AND LARS JONUNG

KNUT WICKSELL WORKING PAPER 2018:5

\section{Working papers}

Editor: F. Lundtofte The Knut Wicksell Centre for Financial Studies

Lund University School of Economics and Management

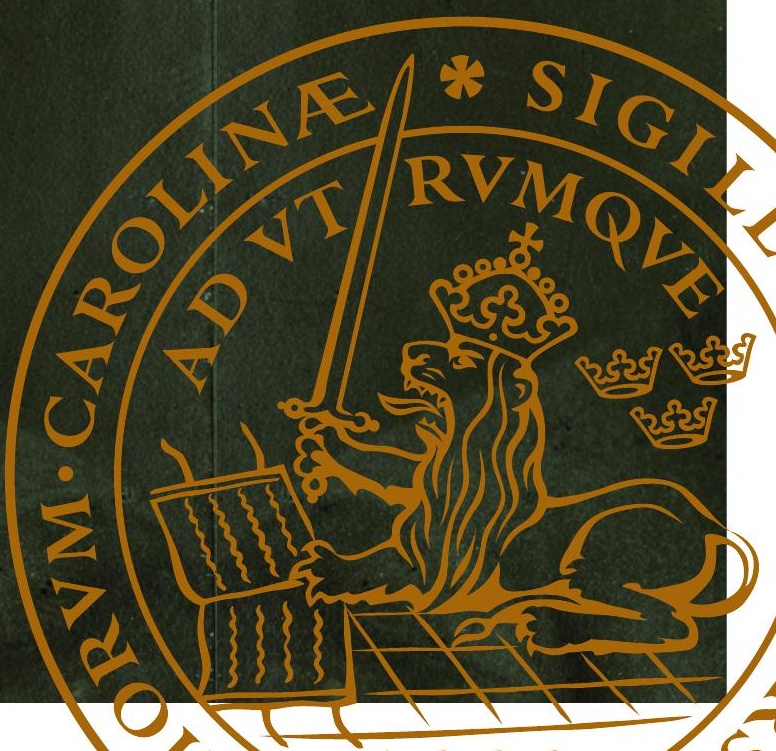





\title{
Iceland should replace its central bank with a currency board
}

\author{
Fredrik NG Andersson and Lars Jonung \\ Department of Economics and Knut Wicksell Centre for Financial Studies, \\ Lund University, Lund
}

October 2018

Prepared for the conference The 2008 Global Financial Crisis in Retrospect, Reykjavik, Iceland on August 30-31, 2018, organized by Robert Aliber and Gylfi Zoega.

\begin{abstract}
Since its independence in 1918, Iceland has tried a number of monetary regimes. They have all failed to provide monetary stability. Iceland is too small to conduct an independent monetary policy. What should Iceland do? We arrive at the conclusion that a currency board with the euro as the reserve currency is the best choice. A currency board delivers monetary stability through exchange rate stability. In contrast, a flexible exchange rate for Iceland serves as a chock amplifier. However, a currency board requires domestic reforms preferably before it is established to enhance price and wage flexibility as well as proper regulations of the financial system to minimize the risk of future financial crises.
\end{abstract}

Key words: Monetary policy, inflation targeting, currency board, Iceland, Central Bank of Iceland.

JEL code: E42, E43, E44, E52, E58, E62, F33, F62 and G01.

Email address: Fredrik_n_g.Andersson@ @nek.lu.se and Lars.Jonung@nek.lu.se 


\section{Iceland should replace its central bank with a currency board}

\section{Introduction ${ }^{1}$}

In recent decades inflation targeting has emerged as a popular policy strategy among central banks. The Sedlabanki, the Central Bank of Iceland, has followed this trend since 2001. Current developments, not least the great financial crisis of 2008, show that inflation targeting is not the best choice of monetary policy regime for Iceland. The model behind inflation targeting is primarily designed for large economies - not for a very small economy like Iceland which should properly be classified as a microstate. ${ }^{2}$

In this contribution, we discuss the menu of policy regimes available for Iceland. Each regime is evaluated against the characteristics of the Icelandic economy. We start with a short description of the Icelandic economy. We then examine the costs and benefits of alternative monetary regimes. In our conclusions, we rule out all regimes Iceland has tried since attaining full sovereignty in 1918 as they have all failed to provide economic and financial stability in the long run. We reach the conclusion that Iceland should follow the example of other very small countries, microstates, and settle on a currency board, in this case with the euro as the monetary base currency. ${ }^{3}$ To ensure the sustainability of the currency board, we recommend additional reforms of the labor market and of the fiscal framework of Iceland.

\section{Characteristics of the Icelandic economy}

Iceland is a small economy with about 335,000 inhabitants, located at the periphery of the global economy. The Icelandic krona (ISK) is the smallest currency in the world supplied by an inflation targeting central bank, the Central Bank of Iceland (CBI). Prior to inflation targeting, Iceland tried various monetary policy regimes. The success (or rather failure) of all these regimes are condensed in Figure 1, which displays the exchange rate of the US dollar to the Icelandic currency 1875-2015. The exchange rate has the shape of a staircase, going down. Periods of stability are followed by periods of high volatility and rapid depreciation. All regimes have failed to deliver monetary and financial stability.

\footnotetext{
1 This paper is based on our contribution to the Icelandic government commission that published its final report in June 2018. See Andersson and Jonung (2018). We have benefitted from constructive comments from Kim Abildgren, Thorvaldur Gylfason, Steve Hanke, Ásgeir Jónsson, Thórarinn G. Pétursson, Kurt Schuler and Ásgeir B. Torfason as well as from participants at meetings in Reykjavik where we have presented our views.

${ }^{2}$ See for example the inclusion of Iceland among microstates in https://en.wikipedia.org/wiki/Microstate

${ }^{3}$ For the concept of the microstate and the implications of a microstate for the choice of exchange rate arrangement, see Imam (2010). In a similar vein, Breedon et al (2012) examine the exchange rate policy of 37 small rich economies using Iceland as a benchmark. Here the sample includes countries with a population between 30,000 and 3,000,000, thus some are larger than microstates.
} 


\section{[FIGURE 1]}

External shocks from the world economy is a major factor behind the failure of the monetary regimes adopted by Iceland. Because Iceland is dependent on a few export goods and services, a major international shock to any of these sectors has a profound effect on the Icelandic economy. Fish used to be the staple export; later aluminum and most recently tourism have become important sources of foreign currency. Almost all other goods, from cars to food, are imports.

There are clear diseconomies of scale due to the small size of the Icelandic economy. ${ }^{4}$ The restricted domestic market limits specialization, implying that Iceland must turn to foreign markets to reap the benefits of specialization, making the economy vulnerable to changes in external conditions. It also implies that the exchange rate is an important economic variable. Small changes in the exchange rate have large effects on domestic economic welfare.

The weak quality of governance by the public sector is another factor behind monetary instability. The record of economic policymaking in Iceland, not least from the recent financial crisis, suggests that close ties between business groups and politicians in power have had an unduly large influence on policy outcomes. ${ }^{5}$ On the other hand, Iceland is exceptional in the sense that a number of bankers have received jail sentences, although it is an open question to what extent major culprits have been able to evade prosecution.

Being small also may have some advantages. For example, the public's preferences may more easily be reflected through the political system in a small country than in a large one. The volatile political performance of Iceland in recent decades lends mixed credence to this view. Smallness may invite economic as well as political instability.

To sum up, the choice of monetary policy regime for Iceland must be based on the fact that Iceland is a very small open economy, heavily reliant on foreign trade and finance. We should think about Iceland as a microstate - not comparable with other small economies like Iceland's Nordic friends Denmark, Norway and Sweden.

\section{Choosing the proper monetary regime}

The monetary policy regimes Iceland can choose between are displayed in Table 1. Fundamentally, it is a choice between a flexible exchange rate, allowing the market to set the value of the domestic currency, or a fixed exchange rate where the value of the currency is guaranteed by the central bank against another currency or basket of currencies. It is possible to break down the two major options into sub-sets reflecting the extent to which the rate is fixed or flexible and additional domestic policy goals are considered.

\footnotetext{
${ }^{4}$ See Gylfason (2009).

${ }^{5}$ See Sibert (2011) and Gylfason $(2015,2018)$.
} 


\section{[TABLE 1]}

Which regime should Iceland choose? The theoretical literature does not provide a clear answer. However, history offers a few guidelines: First, rules-bound policy regimes provide greater economic stability. Second, the regime should be credible. Third, monetary policy alone cannot provide economic stability. Fiscal policy and labor market performance are crucial for ensuring monetary stability. For example, weak public finances or excessive wage claims can threaten the stability of any monetary policy regime. The reason credible and rules-based regimes are more successful is that the government and the private sector have aligned their expectations and thus their behavior according to the rules of the monetary regime. Public and private behavior thus supports the policy of the central bank, making it easier for the central bank to reach its target.

Our conclusion so far is that whatever regime Iceland chooses, it should be rules-based, credible, supported by the government through its fiscal policy and accepted by the public/the voters as reflected in wage agreements and expectations consistent with the regime.

\section{Alternative monetary regimes for Iceland}

Since the 1960s, economists have discussed the choice of monetary policy regime starting from the macroeconomic trilemma, stating that among the three policy goals of a fixed exchange rate, free capital flows and monetary independence, no more than two goals are fully achievable at the same time. ${ }^{6} \mathrm{~A}$ fixed exchange rate and free capital flows form a common combination in economic history, with the classical gold standard as the prime illustration. Monetary independence and free capital movements is another possible combination; presently inflation targeting is the principal example. However, monetary independence is incompatible with a fixed exchange rate, unless there are controls over cross-border capital flows.

In recent decades, researchers have challenged the traditional trilemma framework. Rather than a trilemma, they argue that financial globalization has reduced the problem to a dilemma given the scale of global financial markets and financial integration in recent years. ${ }^{7}$ The only choice is between monetary independence through capital controls or monetary dependence through no capital controls. ${ }^{8}$

In short, the monetary autonomy of countries on a floating exchange rate that are financially well integrated is limited - although it is an open question how limited. The main channel limiting autonomy is the co-movement of interest rates across countries regardless of the

\footnotetext{
${ }^{6}$ The trilemma can be traced back to the Mundell-Fleming approach developed in the 1960s. It received considerable attention in the debate concerning optimal currency unions and the common European currency. Work in the 1990s gave empirical support to the trilemma. See Obstfeld and Taylor (2017) for a current review.

${ }^{7}$ See for example Rey (2013).

${ }^{8}$ See e g Obstfeld and Taylor (2017).
} 
exchange rate arrangement. Here, the Federal Reserve and the ECB hold a key role because of the sheer volume of financial assets denominated in dollars and euros, and thus depending on US and euro interest rates. Changes in the Federal Reserve or the ECB policy rate automatically spreads to smaller economies through financial linkages. Consequently, small countries like Iceland with floating rates and with free capital mobility cannot isolate themselves from the policy decisions made by the Federal Reserve and the ECB.

The policy conclusion is straightforward. If a country wants to keep its domestic monetary independence, even when adhering to a flexible exchange rate, it must consider measures to manage and restrict the flow of cross-border credit. However, such restrictions come with a cost; they are likely to reduce long-term economic growth. Without such restrictions, the central bank is forced to shadow the interest rate path chosen by the major central banks, irrespective of the state of the domestic economy. ${ }^{9}$

The first step is therefore to decide on open or closed borders for capital mobility. Given the limited size of the Icelandic economy and of its domestic financial markets, we recommend open capital markets. Closed capital markets would likely reduce economic growth in the long run. In the globalized economy of today, the use of domestic restrictions on cross-border capital flows is difficult as firms and individuals are intensely involved in commerce and finance across borders. A system of capital controls risks becoming complex, bureaucratic and open for corruption, causing major damage to public trust in the government. Controls should only be used in times of major emergencies. ${ }^{10}$

The second step is to choose between a flexible exchange rate and a fixed exchange rate. Let us first discuss possible regimes based on a flexible exchange rate and then alternative regimes founded on a fixed exchange rate.

\section{Should Iceland target inflation under a flexible exchange rate regime?}

Theoretically, a flexible exchange rate is an option for Iceland. However, recent experience shows that Iceland cannot set its own interest rate policy without capital controls. Since 2001, Iceland has targeted inflation. From 2003 to 2008, inflation was on an upward trajectory. According to the rules of an inflation target regime, interest rates should be raised when inflation is above the target. The Icelandic central bank did increase interest rates - substantially more than the Fed (Figure 2).

In response to higher domestic interest rates, commercial banks, firms and households on Iceland started to borrow from abroad in foreign currencies at lower interest rates, bringing

\footnotetext{
${ }^{9}$ This is well demonstrated by the case of Sweden under inflation targeting. See Andersson and Jonung (2018).

${ }^{10}$ The effectiveness of capital controls in stabilizing the financial system and the economy is an open issue (see, e.g., Klein 2012). However, given the recent experience of destabilizing financial flows, the potential use of capital controls should not be discarded (Rey 2013).
} 
capital into Iceland. Foreign actors entered as well, purchasing ISK-denominated assets offering higher returns than the global average, financing these purchases by borrowing in markets with low interest rates (the "carry trade").

\section{[FIGURE 2]}

Initially, the interest-rate differential between Iceland and the rest of the world contributed to an inflow of capital, an appreciating ISK, a rapidly expanding domestic money stock and credit volume, rising domestic inflation and rising asset prices (Figure 2). The appreciation had positive wealth effects, encouraging rising consumption and rising imports. This process continued until the beginning of the international financial crisis in 2007/08 when the Icelandic krona began to lose value despite a growing interest-rate differential with the rest of the world.

The commercial banking system expanded at an unprecedented scale: compared to the GDP of Iceland it grew from 170 percent in 2003 to 562 percent by 2006 and further to 971 percent in 2008. ${ }^{11}$ A large part of the increase in lending from the Icelandic banks took place in other countries than Iceland, but domestic credit also expanded rapidly. Iceland's membership in the European Economic Area (EEA) gave access to European capital markets that made the increase in lending possible. This process gave rise to the idea that Iceland was turning into an international center for finance. ${ }^{12}$

Given the framework of inflation targeting, the response of the CBI was to raise the policy rate in the hope that a higher policy rate would put a brake on inflation. However, the outcome was the opposite. It contributed to a cumulative process where higher interest rates gave rise to further capital inflows and monetary expansion, not a contraction, and to higher inflation rather than lower inflation.

In short, inflation targeting fueled a highly unstable domestic dynamic process: higher policy rates by the CBI lead to higher asset price, greater private consumption, higher inflation, and higher interest rates. The outcome was growing financial imbalances. Eventually, the process came to a sudden stop. Iceland experienced a deep financial crisis in the fall of 2008. The inflation target and the policy pursued to reach the target was a key factor behind this catastrophic outcome. ${ }^{13}$

Since the crisis, Iceland has returned to a policy of inflation targeting, while relying on capital controls and macroprudential tools, so-called "inflation targeting plus". ${ }^{14}$ Inflation targeting

\footnotetext{
${ }^{11}$ For data on credit see https://www.sedlabanki.is/hagtolur/hagtolur.

${ }^{12}$ See various contributions in Aliber and Zoega (2011) and Jónsson and Sigurgeirsson (2016).

${ }^{13}$ See for example Danielsson (2008) on the role of the targeting regime of the CBI. The experience of inflation targeting in Iceland may be viewed as another example of the "perils of inflation targeting" as discussed by Leijonhufvud (2007).

${ }^{14}$ Capital controls have been lifted over time and were largely abandoned by early 2017, although some restrictions remain. See Central Bank of Iceland (2017) for an assessment of the inflation targeting framework of Iceland before and after the crisis of 2008.
} 
plus has brought inflation down and stabilized it at around 2 percent (Figure 3). However, it is an open question if the CBI will be able to stabilize inflation in the future now that capital controls have been abolished - a step taken in early 2017. To what extent the differences is due to capital controls is uncertain, but it is very likely that the controls have increased the CBI's ability to control inflation in Iceland.

\section{[FIGURE 3]}

To sum up, inflation targeting does not allow a small country such as Iceland to carry out a fully independent monetary policy without facing grave challenges. In a globalized world, full monetary policy independence for Iceland requires capital restrictions, judging from Iceland's recent experience. Such controls have negative effects on the economy in the long run and should be avoided. Consequently, we recommend that Iceland should not opt for a flexible exchange rate.

Let us now turn to fixed exchange rate arrangements in our search for a better alternative.

\section{Benefits and costs of a fixed exchange rate arrangement}

There are several types of fixed exchange rate regimes (Table 1), where they differ concerning how easy it is to adjust the exchange rate. Membership in a monetary union represents one extreme, with very high costs for changing the rate. A fixed but adjustable rate against a foreign currency is the other extreme, where the cost of changing the rate is relatively low. Under a currency board, it is easier to adjust the rate than in a monetary union but harder than under an adjustable fixed rate.

Although each fixed exchange rate regime has unique characteristics, they share similar advantages and disadvantages compared to a flexible rate arrangement. Let us briefly consider their common advantages and disadvantages compared to a flexible rate.

A stable exchange rate facilitates foreign trade, contributing to higher economic growth through greater specialization. For a small country that imports most of its consumer goods, a stable exchange rate also contributes to stable consumer prices. In Iceland, the link between inflation stability and exchange rate stability is strong. From a policy perspective, central banking is simple under a fixed exchange rate; the task of the central bank is limited to maintaining the fixed rate by shadowing the international interest rate.

A disadvantage of a fixed exchange rate is that the exchange rate cannot act as a buffer against economic shocks. A flexible exchange rate may at least partially insulate the domestic economy from some of the effects of either a domestic or an international economic shock. With a stable exchange rate, all adjustments for restoring stability from a shock must come within the domestic economy. The stable exchange rate thus requires that domestic prices and wages are flexible to be viable. A concern with a fixed exchange rate is that may be difficult to obtain the necessary domestic flexibility to adjust to economic shocks. However, countries, such as 
Denmark, have proven that it is possible to maintain a fixed exchange rate for a long period through labor market flexibility.

For a small country such as Iceland that relies on three main export items (tourism, fish and energy), buffering against fluctuations in foreign demand is crucial. A shock to one sector can easily destabilize the entire economy. One option for Iceland would be to establish stabilization funds or buffer funds as complements to a fixed exchange rate. Such funds were established in Finland when Finland joined the euro area in 1999. Several American states have similar systems of "rainy-day funds". To minimize discretionary political interference, such a system of buffering should preferably be designed as an automatic system that increases and decreases taxation based on observable indicators of economic performance such as profit shares, exports, wages and the unemployment rate.

To sum up, to obtain the full benefits of a stable exchange rate, the private sector, including labour unions, must support the exchange rate regime by acting according to its implicit rules. Stabilization funds in one form or another could help against large swings in international demand, making the fixed exchange rate more sustainable.

\subsection{Should Iceland adopt a fixed but adjustable exchange rate?}

A fixed but adjustable rate has many advantages. It provides exchange rate stability and offers a way out of major economic crises. However, it only provides stability if the fixed exchange rate is credible. The ability to adjust the fixed exchange rate should only be in option in major economic crises.

We do not recommend Iceland to adopt a fixed rate for the ISK at this stage. Such a step would require a degree of credibility that Iceland does not command. Financial markets are well aware of the volatile history of the Icelandic currency. A fixed ISK rate would eventually be the subject of speculative attacks - in particular in the absence of Icelandic capital controls. The welfare costs to Iceland of a fixed but adjustable rate would be higher than any conceivable benefits.

\subsection{Should Iceland become a member of a monetary union?}

A monetary union is a geographical area within which only one type of currency circulates as money that serves as the unit of account, the medium of exchange, and the store of value. Within a monetary union, the exchange rate is by definition irrevocably fixed. Vis-à-vis the rest of the world, a monetary union has one exchange rate for converting outside currencies into the common currency.

For a country as small as Iceland, membership in a monetary union would offer several benefits. First, it would facilitate international trade within the monetary union to which Iceland belongs. Second, joining a monetary union would be a way to import monetary stability from the common central bank, fostering macroeconomic stability presuming that the common central 
bank has a credible policy. Third, membership in a monetary union would give Iceland access to international financial markets without the exchange rate risk that an independent currency involves. ${ }^{15}$

These main benefits should be compared to the costs of membership in a monetary union. The prime cost is the loss of an external adjustment mechanism. Without a domestic currency, there is no exchange rate to offset the effect of large external shocks. Nor is there an escape clause that would allow the country to leave the union if the membership of the union destabilizes the economy. Adjustments of prices and wages in relation to other countries, necessary to maintain international competitiveness, are only achievable through flexible domestic wages and prices. Domestic rebalancing can be both difficult and time-consuming, as the experience of the euro area periphery since 2008 illustrates. In Greece, Italy and Portugal prices, wages and living standards have fallen as these economies have tried to regain macroeconomic balance after the financial crisis and the debt crisis.

Much of the balance between the benefits and costs of a monetary union hinges upon the importance of having a flexible exchange rate serving as a shock absorber. For a country like Iceland, its monetary history serves as a guide here, suggesting that a flexible exchange rate has functioned as a chock amplifier. Because central bank policy in Iceland has been a source of instability, the balance shifts in favor of tying the hands of the domestic monetary authorities.

The euro area and the dollar area (the United States) are both an economic and a political union. However, a country can belong to a monetary union without belonging to a political union. In Europe, four small countries (microstates), Andorra, Monaco, San Marino and the Vatican City, use the euro without belonging to the European Union. In addition, Liechtenstein uses the Swiss franc without being in a political union with Switzerland. Several countries in Europe like Albania, Croatia, the Czech Republic and Serbia have widespread use of the euro alongside the national currency. Montenegro and Kosovo are euroised. ${ }^{16}$

Iceland could adopt the euro either by a unilateral decision or by a bilateral agreement. A bilateral route likely implies full membership in the EU. Joining the EU as a full member would be a very political and time-consuming decision that Iceland does not appear to be ready to take in the near future. In our view, the most constructive route for Iceland at this stage is to settle for a unilateral approach, as full EU membership is not a possible option for the moment. This suggests that the advantages of a membership in the euro area can be obtained by a currency board arrangement for Iceland.

\subsection{Should Iceland set up a currency board?}

\footnotetext{
${ }^{15}$ Iceland was once a part of the Scandinavian Currency Union (SCU) because of being under Danish rule. The SCU functioned as a successful monetary union from the early 1870s until the outbreak of World War I (Jonung 2007), providing Iceland with the benefits of being a member of a monetary union.

${ }^{16}$ See ECB (2017).
} 
A currency board is a form of a monetary union. It "is an institution that issues notes and coins convertible into a foreign "reserve" currency at a fixed rate and on demand. It does not accept deposits. As reserves, a currency board holds high-quality, interest-bearing securities denominated in the reserve currency. A currency board's reserves are equal to 100 per cent or slightly more of its notes and circulation, as set by law. (Commercial banks in a currency system need not hold 100 per cent reserves in reserve currency assets against their deposits, though.) The board generates profits (seigniorage) from the difference between the interest earned on the securities that it holds and the expense of maintaining its notes and coin circulation. It remits to the government or to another institution all profits beyond what it needs to cover its expenses and to maintain its reserves at the level set by its rules. The currency board has no discretion in monetary policy; market forces alone determine the money supply. (Here the money supply is defined as the public's holdings of notes and coins plus deposits held with the commercial banking system.)” (Hanke, et al (1992, p. 19)).

In other words, the currency board is a fixed exchange rate arrangement, similar to a membership in a monetary union. Unlike a fixed exchange rate system, there is no risk of a devaluation forced upon the country by outside factors, as the international reserves fully cover all domestic notes and coins in circulation plus commercial banks deposits at the central bank (i.e. the monetary base). The board only issues domestic currency to the extent that it has foreign reserves as backing.

As a rule, small countries have adopted currency board arrangements. ${ }^{17}$ In the 1990s, several countries in Eastern Europe opted for currency boards. For Estonia and Lithuania, a currency board arrangement with the euro as the reserve currency served as a stepping-stone into full membership of the euro area, a strategy that worked well. Outside Europe, Hong Kong is a current example of a "country" with a currency board. ${ }^{18}$

From a monetary viewpoint, the experience of Greenland and the Faroe Islands, Iceland's closest neighbors, is of great interest. Greenland with a population of 56000 inhabitants and the Faroe Islands with a population of roughly the same size, both dependent on fishing like Iceland, are part of the Danish monetary area which has a permanently fixed exchange rate towards the euro. In this way, Greenland and the Faroe Islands have a greater monetary and financial stability than Iceland. Since 1939 when the exchange rate between the Danish and the Icelandic currencies were one-to-one, the Icelandic króna has lost 99,95 percent of its value visà-vis the Danish krone.

\footnotetext{
${ }^{17} \operatorname{Imam}(2010)$.

${ }^{18}$ Sometimes the experience of the convertibility plan of Argentina 1991-2002 is viewed as a case of a failed currency board. However, the convertibility plan did not follow the rules of a currency board. See e.g. Hanke (2008).
} 
Turning to the case of Iceland, the euro would be the prime candidate to serve as the reserve currency of an Icelandic currency board. The EU is the main trading partner of Iceland and the euro is the main foreign reserve currency for Iceland.

Our recommendation that Iceland should establish a currency board is consistent with the conclusions of a recent study of the experience of exchange rate policies of small rich economies: "Thus, in the case of Iceland, our results suggest that a strict peg, such as membership in a currency union or a currency board arrangement, will lead to a more stable exchange rate without adding to macroeconomic fluctuations. We therefore find limited empirical evidence supporting the commonly cited argument that the current flexible exchange rate arrangement facilitates economic adjustments to shocks and thus reduces real economic volatility." (Breedon et al (2012, p. 439)).

A currency board for Iceland based on the euro would have a number of advantages. It would immediately establish exchange rate stability between the Icelandic currency and the euro. Consequently, the risk premium imposed on Icelandic interest rates due to exchange rate uncertainty would be close to zero. Inflation and interest rates in Iceland would rapidly converge to euro area inflation and euro area interest rates. Eliminating the exchange rate risk would encourage foreign investment in Iceland, including direct investment, which tend to be less volatile than portfolio investment.

A currency board would protect the Icelandic currency from political pressure and manipulation better than the present inflation-targeting regime. ${ }^{19}$ Unfortunately, monetary policy in Iceland has a long record of political entanglement, which still reduces the credibility of the Central Bank of Iceland. ${ }^{20}$ The administration of a future currency board would absorb fewer management resources than the present central bank does because a currency board is much simpler to operate effectively. A currency board does not need any proper preconditions to work once it has been set up with a sufficient volume of reserve assets. Moreover, a currency board would most likely start with a stronger reputation than the present CBI.

A psychological advantage with a currency board is that Iceland would be able to retain the present currency unit, the króna, denominated in the Icelandic language. This will appeal to nationalistic sentiments. There would still be a national or domestic currency as perceived by the Icelandic public although it would have a fixed value versus the euro.

Converting the CBI into a full-fledged currency board would be easy. The principal steps for such a transformation are described in Hanke et al (1992, appendix IV). An important issue during this transformation concerns the proper size of the euro reserves of the commercial banking system. In order to withstand any speculative attack on the commercial banking system, commercial bank deposits must be backed with safe euro denominated assets. A

\footnotetext{
${ }^{19}$ A radical solution to minimize political influence on the currency board would be to place its main office outside Iceland, for example in Frankfurt, Germany, close to the ECB.

${ }^{20}$ See chapter 7 in Gylfason et al. (2010), Gylfason (2015) and Sibert (2011).
} 
thorough analysis of the appropriate reserve-to-deposit ratio is required to settle the sufficient level.

There is one major drawback with a currency board: Iceland would give up what limited monetary autonomy it has. In normal times, as argued above, this might not come with any major drawbacks. It may actually be a gain considering the past performance of the monetary policy of Iceland. However, it might be a problem if Iceland were to face an extremely deep economic crisis or shock in the future. With a traditional currency board, there is no authority to act as a lender of last resort.

How should this disadvantage be addressed in the case of Iceland? In the traditional case, the role of the central bank as a lender of last resort is to support temporarily ailing banks during a liquidity crisis. In the severe scenario of a solvency crisis, the resources of a central bank are commonly too limited. In this case, the government, that is, the taxpayers, has to step in if, unlike the case during the crisis in Iceland in 2008, the banking system is not too big to be saved. This would also be a solution under a currency board. In other words, the resolution of a crisis should be managed by other government agencies than the currency board.

Under a currency board arrangement, the negative effects of a financial crisis can be minimized in advance. One way is to impose strict capital requirements on the commercial banking system to limit the probability of a future banking crisis. A second method is to establish a stability fund in normal times that can step in and lend to ailing commercial banks during a crisis. Of course, there is always the option of allowing a failing bank to go out of business. Such a policy would reduce the moral hazard involved in any scheme where the government has incentives to give support.

As monetary history shows, unexpected shocks of great magnitude do occur. Having an escape clause is key to being able to adapt the regime to such shocks. Facing an extreme event, Iceland may always give up the currency board and the fixed exchange rate it implies and return to a floating exchange rate in which the currency board would be transformed into a traditional central bank. Compared to a monetary union, a major advantage of the currency board is that it offers such an escape from the fixed exchange rate in case of an extreme event. It would then be possible to return to a currency board after a temporary "time-out", although with some loss of credibility.

The cost of giving up the currency board should be high, which will ensure that the escape clause would only be used under exceptional circumstances. Strong safeguards should prevent politicians in power from abandoning the currency board at their discretion. For example, the constitution of the currency board should state that a supermajority (say, two-thirds) of the Icelandic parliament would be required to abolish the currency board and turn it into a central bank.

\section{Conclusions}


Which is the best monetary policy regime for Iceland at this stage? After examining the monetary history of Iceland, we rule out a flexible exchange rate with an inflation target for Iceland. The present flexible exchange rate regime has served as a shock amplifier, not as a shock absorber for Iceland. Part of the problem is the free movement of capital. Iceland can only maintain a domestic inflation target over the long run through capital controls. As such controls are very costly and likely to increase corruption, they should be ruled out as a permanent solution.

A fixed exchange rate regime is thus our preferred choice. A fixed exchange rate regime such as that of Denmark requires a high degree of trust in monetary policy as it is sensitive to speculative attacks. Being a microstate, Iceland is not able to create sufficient credibility for such a regime in a financially open world as of today. This leaves us with a monetary union solution by default. However, full euroisation is presently not an option for Iceland for political reasons although the euro is the preferred monetary union alternative.

Consequently, we suggest that Iceland sets up a currency board with the euro as the reserve currency. The króna would persist as the currency unit of Iceland, with the euro circulating as a parallel currency. A currency board would remove the devaluation (exchange rate) risk while giving similar benefits as a monetary union. In addition, a currency board would permit an escape clause if Iceland was hit by an exceptionally large economic crisis.

Combining a rules-based system with some flexibility is essential for the regime to last. Using the escape clause should be costly in order to prevent the Icelandic government from breaking the rules of the currency board under normal circumstances. However, during a major crisis the regime should allow for some flexibility such that a temporary crisis does not turn into a permanent one. The case of Greece and Italy, locked into the euro area, demonstrates the high economic and political costs a rigid regime may have after a negative disturbance.

A currency board would provide transparent and strict policy rules that make monetary policy predictable and credible, less influenced by domestic pressure groups and populist considerations. The international value of the króna would be fixed, which would enhance foreign trade. A currency board would deliver instantaneous monetary stability. However, this is not sufficient for macroeconomic or financial stability. Domestic prices and wages should be more flexible to adjust to changes in competitiveness. The sole task of a currency board would be to exchange króna for euros at the determined rate. It would have no ability to finance government deficits or act as a lender of last resort during a banking crisis.

The introduction of a currency board for Iceland should be accompanied by a wide-ranging reform package to foster fiscal stability, wage and price flexibility, and financial stability. These reforms should be undertaken preferably before or at least at the same time as the currency board is established. We suggest that Iceland consider a system of independent buffer funds to help stabilize the economy in the face of major fluctuations in the demand for its exports. Such funds will help to stabilize the economy and reduce the need for wages and prices to adjust. 
All monetary policy regimes require the support of both the government and the public/the voters. The first step to establish a currency board would be an open and frank dialogue with the Icelandic people about the pros and cons of the board. The aim of the debate would be to inform the public of the reasons to shift to a currency board. Such an open debate is necessary to build trust in the future monetary policy of Iceland.

Iceland once had a stable monetary standard. This was the case prior to World War I when Iceland belonged to the Scandinavian Currency Union, which was part of the international gold standard. Now after a century of independent monetary policies, Iceland should learn a major lesson from its distant past. Stability can be imported by a truly fixed exchange rate. This central lesson can be learnt from the closest neighbors of Iceland as well, Greenland and the Faroe Islands. They are part of the Danish monetary area where the Danish currency is firmly tied to the euro. Iceland can make the same move by establishing a currency board based on the euro - if the political will to do so can by marshalled. 


\section{References}

Aliber, R. and G. Zoega (eds) (2011). Preludes to the Icelandic financial crisis, Palgrave Macmillan.

Andersson, F. NG and L. Jonung (2018), "Lessons for Iceland from the monetary policy of Sweden”, working paper 2018:16, Lund University, Department of Economics. See also https://www.government.is/news/article/2018/06/05/Financial-stability-should-be-prioritisedover-price-stability/

Bordo, M. and L. Jonung (1997). "The history of monetary regimes - some lessons for Sweden and the EMU", Swedish Economic Policy Review, 285-358.

Breedon, F., Pétursson, T. and A. Rose (2012), "Exchange rate policy in small rich economies", Open Economy Reviews, 23:421-445.

Central Bank of Iceland (2017). "Monetary policy based on inflation targeting: Iceland's experience since 2001 and post-crisis changes”, Special publication, no 11, September.

Danielsson, J. (2008). "The first casualty of the crisis: Iceland”, VoxEu.org. http://voxeu.org/article/how-bad-could-crisis-get-lessons-iceland

ECB (2017). The international role of the euro, ECB, July.

Gylfason, T. (2009). “Is Iceland too small”, VoxEU, August 19.

http://voxeu.org/article/iceland-too-small

Gylfason, T. (2015). "Iceland: how could this happen?", chapter 12 in T. Andersen, M. Bergman and S. Hougaard Jensen (eds.) Reform capacity and macroeconomic performance in the Nordic countries, Oxford, Oxford University Press.

Gylfason, T., B. Holmström, S. Korkman, H. Tson Söderström and V. Vihriälä (2010), Nordics in global crisis. Vulnerability and resilience, the Research Institute of the Finnish Economy (ETLA), Taloustieto Oy, Helsinki.

Gylfason, T. (2018), “Ten years after: Iceland's unfinished business”, this volume.

Hanke, S. (2008). "Why Argentina did not have a currency board", Central Banking Journal, vol. 18, no 3, February 56-58.

https://object.cato.org/sites/cato.org/files/articles/hanke_feb2008_argentina_currencyboard.pd $\underline{f}$

Hanke, S., L. Jonung and K. Schuler (1992). Monetary reform for a free Estonia: a currency board solution, SNS förlag, Stockholm. 
Imam, P. (2010). "Exchange rate choices of microstates", IMF working paper 10/12, January.

Jónsson, Á. and H. Sigurgeirsson (2016). The Icelandic financial crisis. A Study into the world's smallest currency area and its recovery from total banking collapse", Palgrave and Macmillan, London.

Jonung, L. (2007). “The Scandinavian Monetary Union 1873-1924”, chapter 6 in P. Cottrell, G. Notaras and G. Tortella (eds), From the Athenian tetradrachm to the euro. Studies in European monetary integration, Ashgate, Aldershot.

Klein, M.W. (2012). Capital controls: Gates versus walls, NBER working paper 18526. http://www.nber.org/papers/w18526

Leijonhufvud, A. (2007). "The perils of inflation targeting”, VoxEU, June 25. http://voxeu.org/article/perils-inflation-targeting

Obstfeld, M. and A. Taylor (2017). "International monetary relations: Taking finance seriously”, Journal of Economic Perspectives, vol 31, no 3, pp 3-28.

Rey, H. (2013). "Dilemma not trilemma: The global financial cycle and monetary policy independence”, paper presented at Jackson Hole Symposium, August 2013. http://www.kansascityfed.org/publications/research/escp/escp-2013.cfm

Sibert, A. (2011). "Overbanked and undersized: Lessons from Iceland", in R. Aliber and G. Zoega (eds), Preludes to the Icelandic Financial Crisis, Palgrave Macmillan. 
Table 1. Alternative exchange-rate arrangements. A stylized view.

\section{A. Floating exchange rates}

A1. Rules-based systems: inflation targeting (Sweden, UK, the euro area), monetary targeting (Bundesbank pre-1999)

A2. Rules-based systems: multiple goals (inflation, employment) (United States)

A3. Discretionary systems: no fixed rules

\section{B. Fixed exchange rates}

B1. Truly fixed rates: a monetary union with a common currency (the euro area)

B2. Fixed, adjustment possible but difficult: currency board (e.g., Hong Kong)

B3. Fixed, adjustment possible but difficult: commodity money (e.g., gold, silver)

B4. Fixed but adjustable: fixed exchange rate vs other currency or basket of currencies (e.g., Bretton Woods, ERM)

Source: Updated version of Table 1 in Bordo and Jonung (1997, p 290). The table ignores the use of capital controls that enhances domestic monetary independence regardless of the regime adopted. 
Figure 1. US dollar/Icelandic krona, 1881-2015. Logarithmic scale.

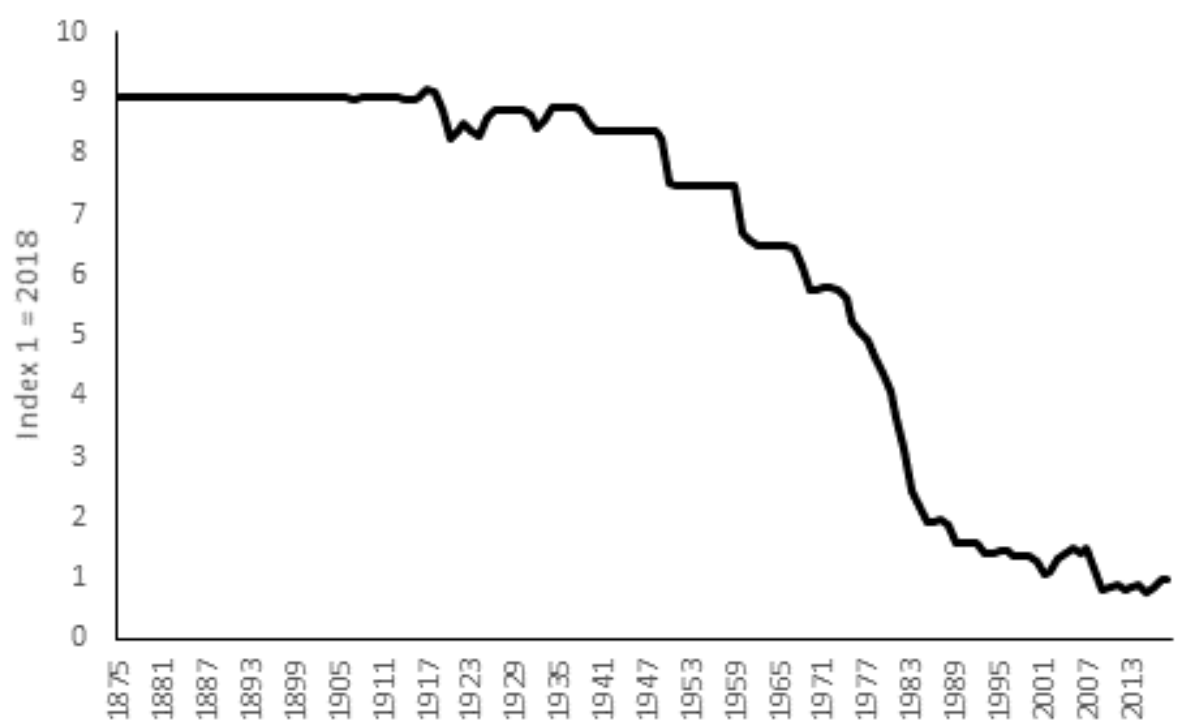

Note: A lower index value implies a weaker Icelandic króna versus the United States dollar. 


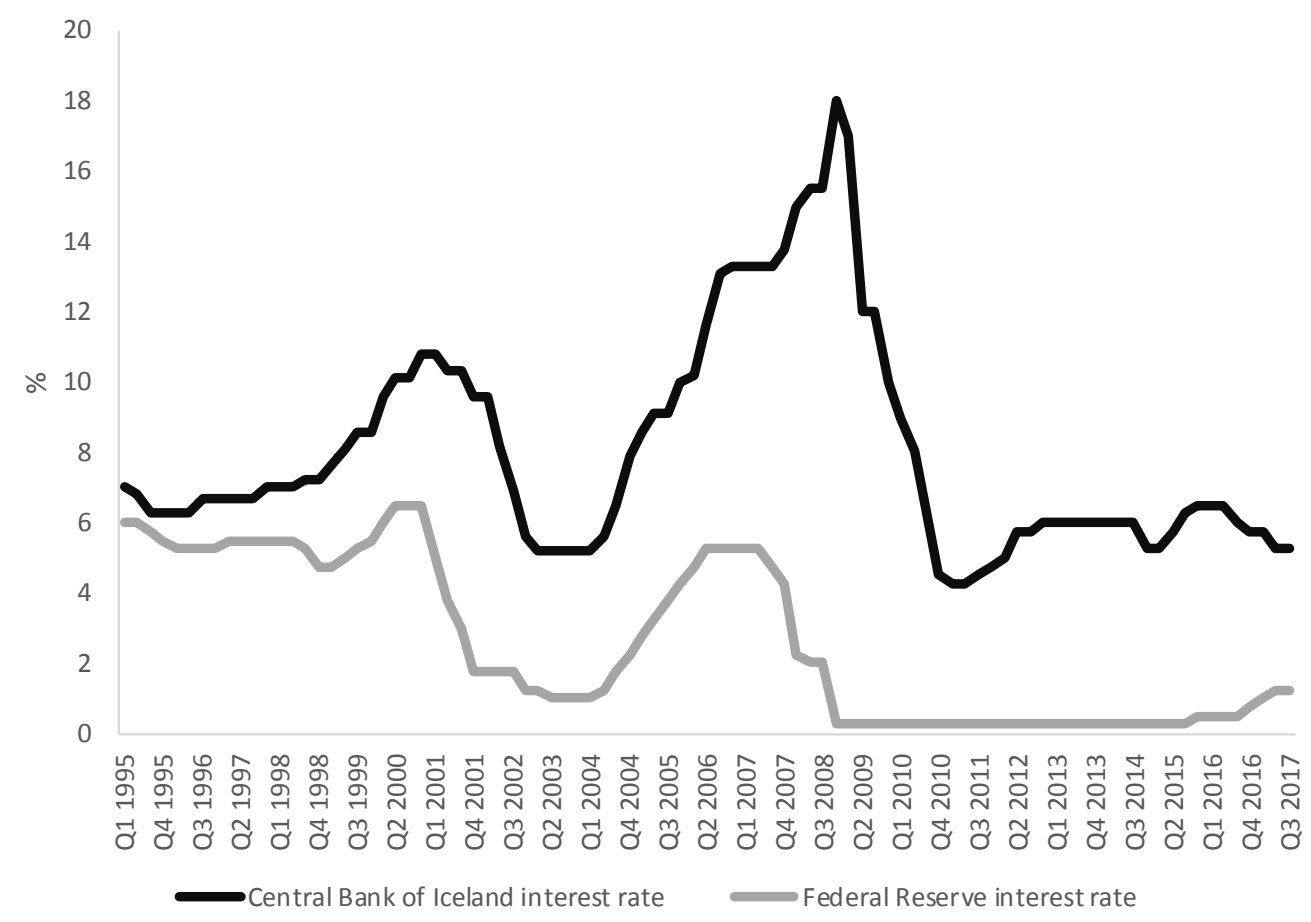

Figure 2. The interest rate of the Central Bank of Iceland and the Federal Reserve, 1995-2017. 


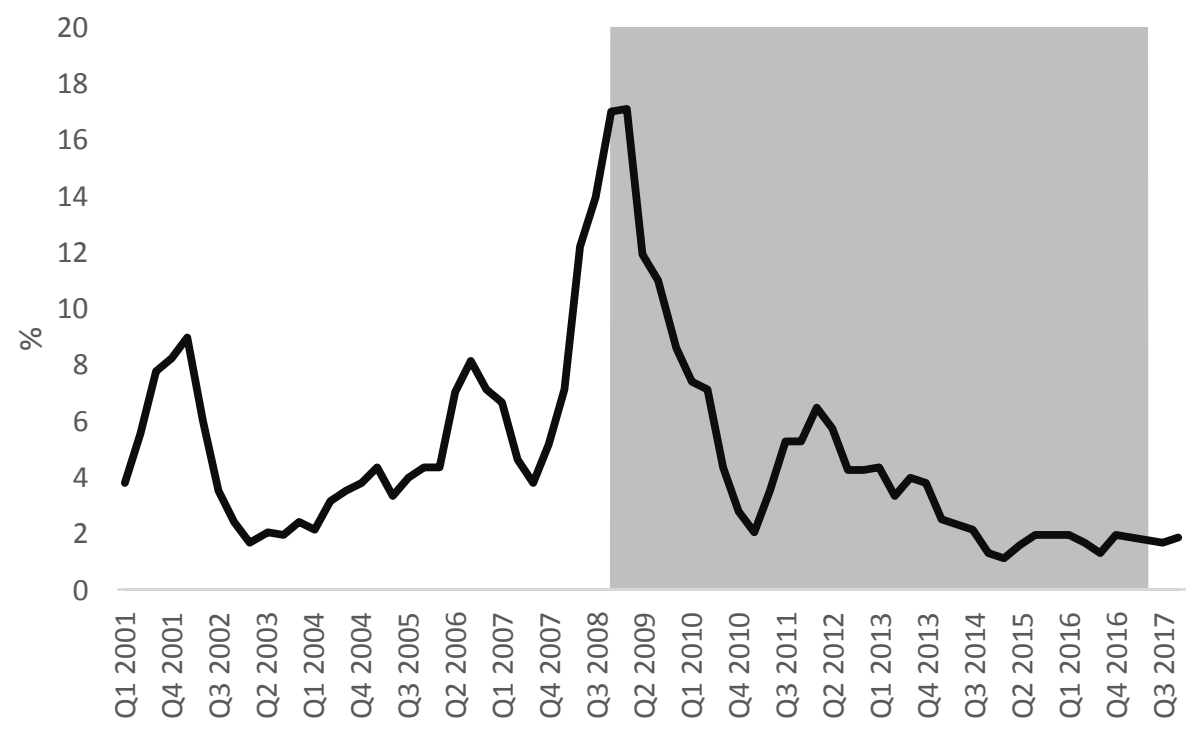

Figure 3. The inflation rate of Iceland, 2001Q1 to 2017Q4. The gray area covers the period with capital controls. 


\section{Iceland should replace its central bank with a currency board}

\section{FREDRIK NG ANDERSSON AND LARS JONUNG}

Since its independence in 1918 , Iceland has tried a number of monetary regimes. They have all failed to provide monetary stability. Iceland is too small to conduct an independent monetary policy. What should Iceland do? We arrive at the conclusion that a currency board with the euro as the reserve currency is the best choice. A currency board delivers monetary stability through exchange rate stability. In contrast, a flexible exchange rate for Iceland serves as a chock amplifier. However, a currency board requires domestic reforms preferably before it is established to enhance price and wage flexibility as well as proper regulations of the financial system to minimize the risk of future financial crises.

Key words: Monetary policy, inflation targeting, currency board, Iceland, Central Bank of Iceland.

JEL code: E42, E43, E44, E52, E58, E62, F33, F62 and G01.

\section{THE KNUT WICKSELL CENTRE FOR FINANCIAL STUDIES}

The Knut Wicksell Centre for Financial Studies conducts cutting-edge research in financial economics and related academic disciplines. Established in 2011, the Centre is a collaboration between Lund University School of Economics and Management and the Research Institute of Industrial Economics (IFN) in Stockholm. The Centre supports research projects, arranges seminars, and organizes conferences. A key goal of the Centre is to foster interaction between academics, practitioners and students to better understand current topics related to financial markets.

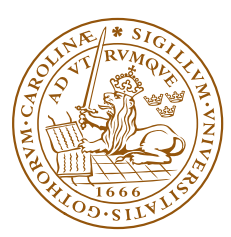

LUND UNIVERSITY

LUND UNIVERSITY

SCHOOL OF ECONOMICS AND MANAGEMENT Working paper 2018:5

school of Economics and Management

The Knut Wicksell Centre for Financial Studies 